Wojciech Bańczyk

Uniwersytet Jagielloński

w.banczyk@onet.eu

\title{
Granice uwzględniania woli testatora z zaburzeniami psychicznymi w polskim prawie spadkowym
}

\author{
The Borders of Acknowledgment of a Testator with Mental Deficiency \\ Under Polish Inheritance Law
}

\begin{abstract}
The article describes the borders of acknowledgement of the actual will of a mentally deficient testator under Polish inheritance law, which is an issue of vital importance in an ageing society. This is done by analysis of those institutions of the inheritance law, the application of which demands examination of the testator's will assumed to be the fundament of this branch of law. By examining the legal premises of testation ability, defects of the statement of will and interpretation of the testament, as well as the practical problems connected therewith, there is an adjustment of those institutions to the specificity of the inheritance law shown together with its further protection of the testator's will in comparison with the general rules of civil law protecting participants of the legal turnover. It is, however, also shown that still far-reaching limitations of the acknowledgement of a testator's will, especially one with the mental deficiency, lead to a lack of legal protection of the actual and doubtless testator's will. This is why the legal solutions acknowledging it to a greater extent are briefly described.
\end{abstract}

Keywords: last will, testament, testator's will, mental deficiency

Słowa kluczowe: testament, wola testatora, zaburzenia psychiczne

\section{Wprowadzenie}

Typowo regulacje prawne nie pozostawiają wątpliwości, że brak woli co do dokonania czynności prawnych ma wpływ na ich skutki prawne. Wzgląd na bezpieczeństwo obrotu prawnego, w tym uzasadnione oczekiwania jego innych podmiotów co do stanowczości składanych im oświadczeń, nie pozwala przy tym na pełne urzeczywistnienie tej reguły. Zasady odnoszące się do sporządzonego w takim stanie testamentu mają jednak szczególny charakter. Z jednej strony, woli testatora przyznaje 
się daleko większy szacunek, niż woli strony zwykłej czynności prawnej, a to z uwagi na tradycyjny respekt dla ostatniej woli, którego pochodzenie wykracza poza normy prawne i jest głęboko zakorzenione $\mathrm{w}$ społeczeństwie $\mathrm{z}$ uwagi na normy etyczne oraz oczekiwanie tego, który szacunek okazuje, że i jego wola będzie kiedyś uszanowana ${ }^{1}$. Nie bez znaczenia pozostaje też brak możliwości skorygowania ani sprecyzowania oświadczenia przez składającego je (gdy okaże się, że nie wywołuje skutków lub wywołuje inne), który sprawia, iż środki ochrony woli takiej osoby muszą być dalej idące niż w świetle reguł ogólnych. Z kolei jednostronność i brak skierowania do jakiegokolwiek innego podmiotu nie wywołują wątpliwości co do kolizji praw spadkodawcy do uwzględnienia jego woli z ochroną innych podmiotów. Z drugiej strony, wola spadkodawcy należy do szczególnie podatnych na zniekształcenia, a to zwłaszcza wobec sporządzania testamentów w coraz bardziej podeszłym wieku. Niezależnie od tego, ma to miejsce nierzadko w stanie różnego rodzaju zaburzeń psychicznych, powodującym czy to niezdolność do właściwego postrzegania rzeczywistości, prawidłowego wyrażenia własnej woli, czy podatność na wpływ innych osób. Jakkolwiek udowodnienie tego wiele lat po sporządzeniu testamentu może być niezwykle trudne, to jednak prawo reaguje na sytuację, gdy w takich okolicznościach sformułowany testament wcale nie ujawnia rzeczywistej woli spadkodawcy. Mając na uwadze specyfikę uwzględniania woli testatora, niniejszy artykuł podejmie analizę polskiego prawa spadkowego w zakresie granic, w jakich uwzględnia ono wolę chorego psychicznie testatora w momencie sporządzania testamentu. W tej kwestii uprawnienie osoby, która zgromadziła majątek za życia, do rozdysponowania go po śmierci, w szczególny sposób kłóci się z potrzebą odebrania jej tego uprawnienia w sytuacji, gdy jej stan psychiczny może rodzić podejrzenia co do niezdolności do prawidłowego działania.

\section{Brak bezpośredniej zależności zdolności testowania od braku zaburzeń psychicznych testatora}

Możliwość wyrażenia przez chorego psychicznie testatora woli w pierwszej kolejności typowego badania testamentu znajduje odzwierciedlenie $\mathrm{w}$ analizie jego pełnej zdolności do czynności prawnych. Zgodnie z art. $944 \$ 1$ kc. ${ }^{2}$ osoba niemająca pełnej zdolności do czynności prawnych nie może bowiem sporządzić testamentu. Przepis ten wyłącza możliwość dokonywania czynności mortis causa przez osoby posiadające jedynie ograniczoną zdolność do czynności prawnych, nawet jeśli w jej

\footnotetext{
1 F. Longchamps de Berier, (w:) W. Dajczak, T. Giaro, F. Longchamps de Berier, Prawo rzymskie. U podstaw prawa prywatnego, Warszawa 2009, s. 258. 
ramach posiadają one pełną zdolność do czynności prawnych w zakresie pewnych przedmiotów (z art. 21 i 22 zd. 1 kc.) $)^{3}$.

Ten surowy wymóg zdolności testowania jako szczególnego fragmentu zdolności do czynności prawnych ${ }^{4}$ ma być uzasadniony szerokim zakresem wolności testowania w prawie polskim ${ }^{5}$. Testator może przecież swoim oświadczeniem w formie testamentu dokonać oceny osób mających zyskać przysporzenie i w nim pominiętych, co ma ogromne znaczenie dla obydwu kategorii osób ${ }^{6}$, a ponadto fundamentalnie wpłynąć na sytuację także innych podmiotów, w tym np. wierzycieli spadkowych. Dlatego też możliwość decydowania o czyimś dziedziczeniu, lub wyłączeniu od niego, ma być pozostawiona tylko osobie, co do której zagwarantowane jest właściwe rozumienie skutków czynności prawnej. Prawo polskie zakłada, że taką osobą jest osoba pełnoletnia, która nie została pozbawiona pełnej zdolności do czynności prawnych z uwagi na chorobę psychiczną, niedorozwój umysłowy lub innego rodzaju zaburzenie psychiczne, w szczególności pijaństwo lub narkomanię, które wpłynęły na jej niezdolność do kierowania swoim postępowaniem (art. $13 \$ 1 \mathrm{kc}$.).

W szczególności przesłanką ubezwłasnowolnienia nie jest jednak sama choroba psychiczna, niedorozwój psychiczny albo innego rodzaju zaburzenie psychiczne, jeżeli nie powodują one niemożności kierowania swym postępowaniem ${ }^{7}$. Z kolei przez pojęcie niemożności kierowania własnym postępowaniem rozumie się brak świadomego kontaktu z otoczeniem oraz brak możliwości intelektualnej oceny swojej sytuacji, swojego zachowania i wywołanych nim następstw ${ }^{8}$.

Samo wystąpienie takich okoliczności nie wpływa od razu na zdolność do czynności prawnych. Jej utratą skutkuje dopiero zakończenie formalnej procedury i wydanie prawomocnego sądowego orzeczenia. Do jego wydania niezbędne zaś jest wydanie opinii przez dwóch lekarzy, mianowicie psychologa i psychiatrę lub neurologa (art. 553 kpc. ${ }^{9}$ ), którzy obok stwierdzenia u badanego zaburzeń psychicznych powinni dokonać analizy jego zdolności kierowania swoim postępowaniem, opartej

3 E. Skowrońska-Bocian, Testament w prawie polskim, Warszawa 2004, s. 31; L. Stecki, (w:) J. Winiarz (red.), Kodeks cywilny z komentarzem, Warszawa 1980, s. 848.

4 E. Skowrońska-Bocian, Testament..., op. cit., s. 29.

5 S. Wójcik, F. Zoll, (w:) B. Kordasiewicz (red.), System prawa prywatnego. Prawo spadkowe. Tom 10, Warszawa 2015, s. 347.

6 S. Wójcik, (w:) J. Piątowski (red.), System prawa cywilnego. Prawo spadkowe, Warszawa 1986, s. 181.

7 Postanowienie SN z dnia 3 grudnia 1974 r., I CR 580/74, Lex nr 1631970; tak samo o tym, że choroba nie ma wpływu na zdolność testowania - postanowienie SN z dnia 6 listopada 2014 r., II CSK 103/14, Lex nr 1573972; postanowienie SN z dnia 30 kwietnia 1976 r., III CRN 25/76, Lex nr 5023.

8 Postanowienie SN z dnia 17 maja 2013 r., I CSK 122/13, Lex nr 1353039.

9 Ustawa z dnia 17 listopada 1964 r. - Kodeks postępowania cywilnego (tekst jedn. Dz.U. z 2016 r. poz. 1822 ze zm.). 
na gruntownej i wnikliwej analizie jego postępowania, w tym zwłaszcza kontaktów $\mathrm{z}$ innymi ${ }^{10}$.

Zdolność testowania nie zależy zatem od nieistnienia po stronie testatora zaburzeń psychicznych - nawet takich, które uniemożliwiają mu kierowanie własnym postępowaniem - brak bowiem w prawie polskim koncepcji naturalnej niezdolności do czynności prawnych ${ }^{11}$. Pojawiają się głosy, że nie jest to stanowisko prawidłowe - tak bowiem chwilowe zaburzenie psychiczne, podobnie jak trwałe zaburzenie, czy brak odpowiedniego wieku świadczą o tym samym, że mózg takich osób nie utrzymał lub nie osiągnął odpowiedniego poziomu, by przetwarzać informacje lub podjąć decyzję - w tym wypadku o samodzielnym ukształtowaniu dziedziczenia - i dlatego powinny łącznie podlegać ocenie w ramach zdolności do czynności prawnych ${ }^{12}$. De lege lata nie budzi jednak wątpliwości, że takie zaburzenia psychiczne zyskają znaczenie dopiero jako podstawa przyszłego ubezwłasnowolnienia. Jego orzeczenie na ich podstawie w żaden sposób nie wpłynie jednak na ważność czynności dokonanej przed utratą zdolności testowania ${ }^{13}$. Będą mogły jedynie posłużyć uwzględnieniu wad oświadczenia woli testatora w momencie składania przez niego takiego oświadczenia.

Należy zatem zauważyć, że rzeczywisty stan psychiczny osoby niekoniecznie jest uwzględniony w jej zdolności do czynności prawnych. Długotrwałość postępowania o ubezwłasnowolnienie i formalny charakter przesłanki zdolności do czynności prawnych nie pozwalają na uwzględnienie chwilowych zmian stanu psychicznego osoby, zarówno w zakresie jej nagłego pogorszenia, jak i tymczasowego polepszenia.

\section{Możliwość dokonywania czynności prawa spadkowego w braku zdolności testowania}

W prawie polskim pojawia się jednak tendencja do odchodzenia od formalnych kryteriów na rzecz rzeczywistego uwzględniania stanu psychicznego osoby w momencie dokonywania czynności prawnej. W szczególności z punktu widzenia prawa spadkowego największe znaczenie ma instytucja przebaczenia, choć istotny wpływ mają na nie także współczesne tendencje w zakresie regulacji ubezwłasnowolnienia.

Przebaczenie jest powszechnie uważane za akt uczuciowy stanowiący wybaczenie krzywd oraz niegodziwości wyrządzonych przez inną osobę. W prawie spadkowym uniemożliwia ono uznanie osoby, której przebaczono, za niegodną dzie-

10 Postanowienie SN z dnia 19 sierpnia 1971 r., I CR 297/71, Lex nr 1324.

11 Postanowienie SN z dnia 6 listopada 2014 r., II CSK 103/14, Lex nr 1573972; E. Skowrońska-Bocian, Testament..., op. cit., s. 31.

12 J. Wierciński, Brak świadomości albo swobody przy sporządzaniu testamentu, Warszawa 2013, s. 78-79; podobnie zwłaszcza J. Gwiazdomorski, Wyjaśnienie w związku z artykułem M. Piekarskiego „Wpływ zakłócenia czynności psychicznych stron na tok procesu”, „Państwo i Prawo” 1961, nr 12, s. 1018.

E. Skowrońska-Bocian, Testament..., op. cit., s. 34 . 
dziczenia (art. 930 kc.) lub wydziedziczenie jej (pozbawienie zachowku, art. 1010 kc. $)^{14}$. W obydwu przypadkach wybaczenie uniemożliwia zastosowanie swoistych sankcji za niewłaściwe zachowanie osoby, które w razie braku przebaczenia pozbawiłyby osobę uprawnioną do pewnego przysporzenia ze spadku. Jest przy tym wyrazem silnego uwzględnienia znaczenia więzów uczuciowych, które przeważają nad zastosowaniem sankcji za naruszenie porządku prawnego. Z kolei symetryczna regulacja prawna oraz zastosowanie wspólnej nazwy instytucji uzasadniają, że mamy do czynienia $\mathrm{z}$ jedną instytucją przebaczenia ${ }^{15}$.

Specyfika przebaczenia leży w tym, że nie jest oświadczeniem woli, a zatem może go dokonać także osoba niemająca zdolności do czynności prawnych, o ile tylko działa z dostatecznym rozeznaniem. Nie jest konieczna jej świadomość, ani chęć spowodowania skutków prawnych ${ }^{16}$. Przebaczenie może być dokonane w dowolnej formie, nawet dorozumianej, o ile przebaczający znał zachowanie, do którego się odnosi, a sama jego czynność była wyraźna ${ }^{17}$. Niemożliwe jest przy tym jego cofnięcie ${ }^{18}$. Jeszcze zaś przed wprowadzeniem art. $65^{1} \mathrm{kc}$. przyjmowało się, że regulacje dotyczące wad oświadczenia woli powinny się stosować do przebaczenia dokonanego pod wpływem braku świadomości, błędu lub groźby, które miały powodować jego bezskuteczność ${ }^{19}$.

W omawianym kontekście warto również zwrócić uwagę na wyrok Trybunału Konstytucyjnego z dnia 7 marca 2007 r. ${ }^{20}$ Choć dotyczył on kwestii niezgodności z Konstytucją RP niedopuszczalności złożenia przez osobę ubezwłasnowolnioną wniosku o cofnięcie ubezwłasnowolnienia, trybunał podjął także dalej idącą refleksję nad istotą ubezwłasnowolnienia w polskim porządku prawnym. W szczególności zaproponował, by rozważyć dokonanie bardziej kompleksowych zmian w zakresie instytucji ubezwłasnowolnienia w prawie polskim, ponieważ obowiązującą tendencją

14 Trzecia regulacja instytucji przebaczenia w kc. mieści się w art. $889 \$ 1$ i dotyczy niedopuszczalności odwołania darowizny z powodu niewdzięczności obdarowanego, któremu darczyńca przebaczył.

15 Por. J. Piątowski, Prawo spadkowe, Warszawa 2014, s. 114.

16 J. Piątowski, Prawo..., op. cit., s. 114; S. Grzybowski, (w:) S. Grzybowski (red.), System prawa cywilnego. Część ogólna. Tom 1, Warszawa 1985, s. 205.

17 E. Skowrońska-Bocian, J. Wierciński, (w:) J. Gudowski (red.), Kodeks cywilny. Komentarz. Spadki. Tom 4, Warszawa 2013, s. 65; J. Piątowski, Prawo..., op. cit., s. 114; J. Kremis, (w:) E. Gniewek, P. Machnikowski (red.), Kodeks cywilny. Komentarz, Warszawa 2013, s. 1579; powściągliwie M. Pazdan, (w:) K. Pietrzykowski (red.), Kodeks cywilny. Komentarz do art. 450-1088, Warszawa 2013, s. 991; odmiennie S. Grzybowski, System prawa..., op. cit., s. 205.

18 J. Kremis, (w:) E. Gniewek, P. Machnikowski (red.), Kodeks..., op. cit., s. 1579; E. Skowrońska-Bocian, (w:) J. Gudowski (red.), Kodeks cywilny. Komentarz. Spadki. Tom 4, Warszawa 2013, s. 58; J. Piątowski, Prawo..., op. cit., s. 114; odmiennie S. Grzybowski, (w:) S. Grzybowski (red.), System..., op. cit., s. 205.

19 M. Pazdan, (w:) K. Pietrzykowski (red.), Komentarz..., op. cit., s. 991; por. E. Skowrońska-Bocian, J. Wierciński, (w:) J. Gudowski (red.), Kodeks..., op. cit., s. 258. 
staje się odchodzenie od sztywnego ograniczania praw i wolności osób chorych psychicznie, upośledzonych lub uzależnionych na rzecz regulacji bardziej elastycznych, dopasowywanych do konkretnych sytuacji przez sąd orzekający w danej sprawie.

\section{Nieważność testamentu $\mathrm{z}$ uwagi na wady oświadczenia woli testatora}

W razie ustalenia spełnienia formalnej, wstępnej, a zarazem jednoznacznej przesłanki zdolności do testowania jako pełnej zdolności do czynności prawnych, możliwe jest dokonanie bardziej skomplikowanego badania rzeczywistego stanu psychicznego testatora w momencie sporządzania testamentu ${ }^{21}$. Dokonuje się tego na podstawie szczególnych przepisów dotyczących trzech wad oświadczeń woli, mających znaczenie z punktu widzenia sporządzania testamentu (art. $945 \$ 1 \mathrm{kc}$.). W opisanych dalej granicach biorą one pod uwagę specyfikę testamentu i zasady prawa spadkowego, w tym dalej idącą ochronę testatora oraz jego woli. Taka możliwość zachodzi w szczególności wobec braku potrzeby ochrony interesów innych uczestników obrotu, co ma miejsce w przypadku wad oświadczeń woli regulowanych przepisami części ogólnej prawa cywilnego ${ }^{22}$. Ponadto $\mathrm{z}$ uwagi na jednostronność czynności prawnej sporządzenia testamentu brak wśród nich np. pozorności jak z art. 83 kc., bo pozorne mogą być tylko czynności składane innej osobie ${ }^{23}$.

Pierwszą z nich jest stan wyłączający świadome lub swobodne podjęcie decyzji i wyrażenie woli przez testatora. Powodować może go każda pozostająca po stronie testatora przyczyna, nie tylko zaburzenie psychiczne ${ }^{24}$, przy czym z całą pewnością właśnie te będą miały największe znaczenie i na nie zostanie położony nacisk w niniejszym artykule. B. Lewaszkiewicz-Petrykowska wskazywała, że ma on miejsce, gdy całkowicie wyłączona jest możliwość dokonania wolnego wyboru, a zaburzenia psychiczne w całości determinują decyzję testatora ${ }^{25}$. Podnosi się jednak, że znacze-

21 M. Pazdan, (w:) M. Safjan (red.), System prawa prywatnego. Część ogólna. Tom 1, Warszawa 2012, s. 1079-1080.

22 B. Lewaszkiewicz-Petrykowska, Wady oświadczenia woli przy sporządzaniu testamentu, (w:) B. Kordasiewicz, E. Łętowska (red.), Prace z prawa cywilnego wydane dla uczczenia pracy naukowej profesora Józefa Stanisława Piątowskiego, Wrocław 1985, s. 202; E. Skowrońska-Bocian, Testament..., op. cit., s. 37.

23 A. Mączyński, Wpływ wad oświadczenia woli na ważność testamentu, „Rejent” 1991, nr 7-8, s. 25.

24 Postanowienie SN z dnia 14 grudnia 2011 r., I CSK 115/11, Lex nr 1112728; B. Lewaszkiewicz-Petrykowska, Wady..., op. cit., s. 204; S. Wójcik, F. Zoll, (w:) B. Kordasiewicz (red.), System..., op. cit., s. 351. Nie jest przy tym to rozwiązanie odmienne od przyjętego w art. 82 kc., w którym wskazano, że w odniesieniu do ogólnych wad oświadczeń woli wyłączenie świadomości lub swobody powzięcia decyzji i wyrażenia woli powodują jedynie w szczególności choroba psychiczna, niedorozwój umysłowy albo inne zaburzenie psychiczne - J. Wierciński, Brak..., op. cit., s. 92-93.

25 B. Lewaszkiewicz-Petrykowska, Wady..., op. cit., s. 206; zob. także postanowienie SN z dnia 14 grudnia 2011 r., I CSK 115/11; postanowienie SN z dnia 21 kwietnia 2004 r., III CK 523/02, Lex nr 585812. 
nie będzie miało już takie zaburzenie, które wpływa decydująco na fakt sporządzenia testamentu ${ }^{26}$, czy takie, które będzie przyczyną rozrządzenia, a bez którego nie byłoby ono dokonane ${ }^{27}$. W tym zakresie zwłaszcza J. Wierciński proponuje funkcjonalne podejście do oceny świadomości lub swobody testatora, przy którym wystarczające ma być, by rozumiał on konkretną czynność (rozrządzenie) i jej znaczenie dla jego majątku; osób, które będą jej beneficjentami oraz osób, które na jej podstawie są pozbawione korzyści ${ }^{28}$, zaś przy jej sporządzaniu mógł swobodnie i niezależnie wyrazić swoją wolę $e^{29}$.

Przyjmuje się, że świadome powzięcie decyzji i wyrażenie woli to takie, w którym testator jasno przemyślał, komu oraz dlaczego chce przekazać majątek ${ }^{30}$. W tym zakresie wymóg świadomości konsekwencji czynności jest niższy niż przy czynnościach inter vivos, co uwzględnia fakt, że testament zwykle chce sporządzić osoba o słabszej kondycji umysłowej z uwagi na wiek lub choroby ${ }^{31}$.

Z tej przyczyny nie powinno się też kwalifikować testamentu osoby ograniczonej umysłowo jako sporządzonego bez świadomości, jeśli taki testator przez całe życie był w stanie utrzymać siebie i założoną rodzinę ${ }^{32}$. Nawet testament osoby, która krótko po jego sporządzeniu popełniła samobójstwo, nie może automatycznie być uważany za sporządzony w stanie braku świadomości ${ }^{33}$. Bez znaczenia pozostanie także fakt, że testator cierpiał na chorobę psychiczną, jeśli testament sporządził w momencie przejściowej świadomości (lucidum intervallum) ${ }^{34}$. J. Pionkowski wyrażający w tym zakresie pogląd odmienny ${ }^{35}$ wskazuje nawet, że stan niewystarczającej świadomości może mieć czy nawet po ustaniu zaburzeń, które jednak wciąż utrzymują swoje efekty, bądź nie w pełnym zakresie ustały ${ }^{36}$, przy czym w obydwu tak analizowanych przez niego sytuacjach należy stwierdzić, że zamiast przejściowej świadomości, czy

26 Wyrok SN z dnia 7 lutego 2006 r., IV CSK 7/05, Lex nr 180191; wyrok SN z dnia 24 maja 2005 r., V CK 659/04, Lex nr 180821; J. Pionkowski, Nieważność testamentów osób wykazujących zaburzenia psychiczne, „Nowe Prawo” 1963, nr 2, s. 185.

27 Tak w odniesieniu do znaczenia urojenia jako wyłączenia świadomości lub swobody testatora J. Wierciński, Brak..., op. cit., s. 152.

28 Ibidem, s. 91.

29 Ibidem, s. 220.

30 J. Pionkowski, Nieważność..., op. cit., s. 186.

31 J. Wierciński, Brak..., op. cit., s. 90.

32 J. Pionkowski, Nieważność..., op. cit., s. 192.

33 E. Skowrońska-Bocian, Testament..., op. cit., s. 41; J. Wierciński, Brak..., op. cit., s. 207; odmiennie J. Pionkowski, Nieważność..., op. cit., s. 191, wedle którego zawsze jest to podstawą do ich kwestionowania.

34 E. Skowrońska-Bocian, (w:) J. Gudowski (red.), Kodeks..., op. cit., s. 119.

35 J. Pionkowski, Nieważność..., op. cit., s. 196 - o tym, że w takim stanie też nieważny, bo choroba psychiczna w takim stadium dalej ma ten skutek, że przerwała ciągłość życia społecznego testatora i dalej ma wpływ na jego postępowanie. Ibidem, s. 190-191. 
powrotu świadomości, miał miejsce jeszcze wciąż ich brak i to on w istocie musiałby być przyczyną takiego rozstrzygnięcia.

Ocena świadomości, zdaniem J. Wiercińskiego, nie powinna abstrahować od treści rozrządzeń. Jeżeli decyzja testatora jest naturalna i zgodna z zasadą ochrony rodziny, to założyć można poczytalność spadkodawcy, podczas gdy jego ekscentryzm czy niekonwencjonalność, wyrażone kształtem rozrządzeń, mogą budzić wątpliwości i przemawiać raczej za brakiem świadomości ${ }^{37}$. W tym zakresie wolność testowania osób z zaburzeniami psychicznymi ma działać nie tylko w interesie rodziny, ale także samych testatorów przed takimi rozrządzeniami, na podstawie których postąpiliby inaczej, niż gdyby ich wola nie była wypaczona ${ }^{38}$.

Swobodne powzięcie decyzji i wyrażenie woli to natomiast takie, w którym testator nie kieruje się motywami intelektualnymi lub pobudkami uczuciowymi o charakterze chorobliwym ${ }^{39}$. Wskazuje się jednak coraz częściej, że ograniczenie zastosowane przez B. Lewaszkiewicz-Petrykowską do jedynie takich ograniczeń swobody, które mają źródło wewnętrzne, jest zbyt wąskie, a hipoteza przepisu powinna obejmować także przypadki, w których testator pozostaje pod dominującym wpływem sugestii innych osób ${ }^{40}$. Szczególną sytuacją, w której to ostatnie może mieć miejsce jest obecność osoby zainteresowanej rozrządzeniem podczas składania oświadczeń ${ }^{41}$.

Kwestie zarówno świadomości, jak i swobody przy sporządzaniu testamentu podlegają też wykazaniu przez tego, kto się na nie powołuje, a zatem kwestionującego testament. Jeżeli jednak taka osoba przedstawi okoliczności wskazujące na zaburzenia psychiczne spadkodawcy, to potem powołujący się na ważność testamentu będzie musiał wykazać brak ich przełożenia się na brak świadomości lub swobody testatora $^{42}$.

Drugą z podlegających rozpatrzeniu wad oświadczenia woli testatora jest jego błąd popełniony przy sporządzaniu testamentu. Podlega przy tym szerszej regulacji niż w części ogólnej, z której jednak czerpie jako ze źródła definicji błędu, czyli rozdźwięku między rzeczywistością a przeświadczeniem. Będzie miał przy tym znaczenie także, gdy dotyczy motywacji testatora czy jakiejkolwiek innej okoliczności,

37 J. Wierciński, Brak..., op. cit., s. 83-84.

38 Ibidem, s. 85.

39 B. Lewaszkiewicz-Petrykowska, Wady..., s. 205-206; zob. także postanowienie SN z dnia 14 grudnia 2011 r., I CSK 115/11; J. Pionkowski, Nieważność..., op. cit., s. 187; E. Skowrońska-Bocian, Testament..., op. cit., s. 40; J. Wierciński, Brak..., op. cit., s. 221.

40 Postanowienie SN z dnia 21 kwietnia 2004 r., III CK 523/02, Lex nr 585812; J. Pionkowski, Nieważność..., op. cit., s. 187; E. Skowrońska-Bocian, Testament..., op. cit., s. 40; J. Wierciński, Brak..., op. cit., s. 221. J. Wierciński, Brak..., op. cit., s. 240, wskazuje zarazem, że w razie braku możliwości uwzględnienia takich okoliczności, powinny one mieć znaczenie z perspektywy zastosowania art. $58 \S 2 \mathrm{kc}$.

41 M. Kowanetz, E. Skupień, Możliwości oceny świadomości i swobody podejmowania decyzji w trakcie dokonywania czynności przez notariuszy, „Rejent” 2009, nr 7-8, s. 86. 
przyszłej lub przeszłej, faktu lub prawa, która miała istotne znaczenie i to wyłącznie z punktu widzenia testatora (ocena subiektywna) ${ }^{43}$. Skutek ten nastąpi, nawet jeśli testator dokonywał oceny w sposób nierozsądny, co potwierdza funkcjonowanie w tym zakresie teorii woli ${ }^{44}$. Nie musi być także jedyną, samoistną przyczyną niezgodności testamentu $\mathrm{z}$ wolą testatora ${ }^{45}$. Wystarczające jest bowiem, że bez popełnienia błędu nie sporządziłby on testamentu tej treści ${ }^{46}$, przy czym wskazuje się też, że wystarczające będzie uzasadnione przypuszczenie w tym zakresie ${ }^{47}$. Wprowadzenie zaś w błąd, choć przybliża się do pozbawienia swobody, różni się od niej tym, że stanowi bardziej oszustwo osoby obcej, niż wywarcie wpływu przez osobę pozostającą w koniecznej relacji zaufania, by ten wpływ można było wywierać ${ }^{48}$.

Trzecią wadą oświadczenia woli testatora jest pozostawanie przez niego pod wpływem groźby, a zatem wytworzenia stanu niebezpieczeństwa, który rodzi obawę paraliżującą swobodę testatora ${ }^{49}$. Ponadto każdą groźbę, nie tylko poważną, bierze się pod uwagę jako wadę oświadczenia woli, o ile tylko wpłynęła na sporządzenie testamentu, a każda groźba, która naruszyła proces podejmowania decyzji przez testatora, będzie uważana za bezprawnąa ${ }^{50}$ Groźba musi też prowadzić do określonego celu, przy czym żądanie złożenia określonego oświadczenia woli przez grożącego nie musi być wyraźnie wypowiedziane ${ }^{51}$. Należy również wskazać, że groźba jako taka pozbawia testatora swobody, przy czym różni się tym, że czyni to w ten sposób, iż tworzy po stronie testatora poczucie obawy ${ }^{52}$.

Szczególna sytuacja ma miejsce w razie, gdy po stronie testatora w ogóle nie zachodziła wola testowania. Przykładami takich sytuacji może być zarówno brak świadomości testatora, że sporządza testament czy woli jego sporządzenia, jak również sporządzenie przez niego dokumentu o zewnętrznym kształcie testamentu, ale bez zamiaru spowodowania przez niego skutków prawnych. W obydwu takich przypadkach będzie zachodziła sytuacja analogiczna do wad oświadczeń woli przy sporządzaniu testamentu, skutkująca nieważnością ${ }^{53}$. W szczególności znajduje to

E. Skowrońska-Bocian, (w:) J. Gudowski (red.), Kodeks..., op. cit., s. 120; zob. także postanowienie SN z dnia 29 października 2003 r., III CK 325/02; B. Lewaszkiewicz-Petrykowska, Wady..., op. cit., s. 208; S. Wójcik, F. Zoll, (w:) B. Kordasiewicz (red.), System..., op. cit., s. 352.

44 E. Skowrońska-Bocian, Testament..., op. cit., s. 43.

45 M. Pazdan, (w:) K. Pietrzykowski (red.), Komentarz..., op. cit., s. 1026.

46 B. Lewaszkiewicz-Petrykowska, Wady..., op. cit., s. 207-209.

47 E. Skowrońska-Bocian, Testament..., op. cit., s. 43.

48 J. Wierciński, Brak..., op. cit., s. 249.

49 B. Lewaszkiewicz-Petrykowska, Wady..., op. cit., s. 210; E. Skowrońska-Bocian, Testament..., op. cit., s. 44.

50 E. Skowrońska-Bocian, Testament..., op. cit., s. 45; S. Wójcik, F. Zoll, (w:) B. Kordasiewicz (red.), System..., op. cit., s. 353.

51 B. Lewaszkiewicz-Petrykowska, Wady..., op. cit., s. 210.

52 J. Wierciński, Brak..., op. cit., s. 251.

53 S. Wójcik, F. Zoll, (w:) B. Kordasiewicz (red.), System..., op. cit., s. 348. 
uzasadnienie w systemowej spójności takiego rozwiązania ze skutkami okoliczności z art. $945 \$ 1$ kc. oraz wspólnej procedurze ograniczonego czasowo powołania się na nieważność testamentu, która adekwatnie chroni bezpieczeństwo i stabilność obrotu. W razie przyjęcia koncepcji nieistnienia testamentu ${ }^{54}$, możliwe byłoby powołanie się na nią poza powyższymi ograniczeniami, mimo że za ich zastosowaniem stoją takie same racje.

Choć to wbrew literalnemu brzmieniu kc., wobec wystąpienia wad oświadczenia woli testatora należy stwierdzić, że redukcja teleologiczna pozwala przyjąć, iż testament będzie nieważny częściowo, jeśli wada dotyczyła tylko takiej części ${ }^{55}$. Nie jest bowiem zgodne z celem regulacji, by nieważność mało znaczącego rozrządzenia miała podważyć cały testament.

Tak samo jak testament nieważne będzie odwołanie testamentu, które w tym samym zakresie jak testament wywiera wpływ na losy majątku spadkowego po śmierci testatora ${ }^{56}$. Zastanawiające jest przy tym, w jakim zakresie można stosować prawa i obowiązki dla czynności spadkodawcy prowadzącej do przejścia majątku na wypadek śmierci na podstawie przepisów szczególnych (art. $922 \$ 2$ in fine kc. np. w zw. z art. 56 ust. 1 ustawy Prawo bankowe). W zakresie, w jakim np. zapis bankowy na rzecz konkretnej osoby powstaje na podstawie swobodnego oświadczenia spadkodawcy wiążąco kierowanego do banku i wywoła skutki dopiero po śmierci, jest podobny do testamentu na tyle, by przepisy o wadach oświadczenia woli testatora stosować do zapisodawcy bankowego w miejsce przepisów ogólnych, w drodze analogii.

W razie stwierdzenia wystąpienia wad oświadczenia woli, testament będzie nieważny, a wtedy będzie miało miejsce dziedziczenie ustawowe. Art. $945 \$ 2$ kc. stawia jednak granice czasowe dla ustalenia takiej nieważności - trzy lata od dowiedzenia się o przyczynie nieważności, a w każdym razie dziesięć lat od otwarcia spadku. Po tym okresie nie nastąpi jednak konwalidacja nieważnego testamentu, a jedynie zakaz dowodzenia okoliczności świadczących o nieważności ${ }^{57}$. Mając na uwadze upływ czasu po śmierci testatora, a także czas między sporządzeniem testamentu a śmiercią, wzrastają bowiem trudności z rzeczowym wykazaniem zaburzeń psychicznych po stronie testatora, przy czym skutek z omawianego przepisu wystąpi również, gdyby

54 Tak M. Pazdan, (w:) K. Pietrzykowski (red.), Komentarz..., op. cit., s. 1026; E. Skowrońska-Bocian, (w:) J. Gudowski (red.), Kodeks..., op. cit., s. 117.

55 S. Wójcik, F. Zoll, (w:) B. Kordasiewicz (red.), System..., op. cit., s. 354; podobnie co do wniosku B. Lewaszkiewicz-Petrykowska, Wady..., op. cit., s. 212; A. Mączyński, Wpływ..., op. cit., s. 35; L. Stecki, (w:) J. Winiarz (red.), Kodeks..., op. cit., s. 849.

56 B. Lewaszkiewicz-Petrykowska, Wady..., op. cit., s. 203; A. Mączyński, Wpływ..., op. cit., s. 35.

57 A. Mączyński, Wpływ..., op. cit., s. 31-34. 
zaburzenia te były niekwestionowane i wykazane niewątpliwym dowodem (np. pamiętnikiem testatora) ${ }^{58}$.

Choć wywołuje to skutki zbliżone do wzruszalności, to jednak nie tyle strony czynności mogą pozbawić ją ważności, ale mogą to uczynić wszystkie podmioty posiadające interes prawny ${ }^{59}$, w tym liczące na potencjalną korzyść ze spadku ${ }^{60}$. Ma to miejsce w drodze odrębnego powództwa lub w toku sprawy o stwierdzenie nabycia spadku lub o uchylenie (zmianę) postanowienia w tej kwestii.

W tym zakresie ograniczenie czasowe powoływania się na nieważność testamentu z uwagi na wady oświadczenia woli prowadzi do tego, że testament dotknięty wadą może być uznany za wyraz prawdziwej i swobodnej woli spadkodawcy, co pozostaje w jaskrawej sprzeczności z podstawowymi założeniami prawa spadkowego ${ }^{61}$. Wola spadkodawcy nie do końca podlega też uwzględnieniu wobec tylko negatywnych skutków nieważności z uwagi na wady oświadczenia woli testatora, a to dlatego, że nie będzie możliwe wypełnienie jego rzeczywistej woli, nawet jeśli będzie znana ${ }^{62}$.

W zakresie wad oświadczenia woli testatora, jego rzeczywisty stan psychiczny jest bardziej chroniony, niż w przypadku ogólnej regulacji. Należy jednak doprecyzować, że wady oświadczeń woli są kategorią normatywną. Nie dają bowiem możliwości sędziemu, by swobodnie uznał, że w danej sytuacji doszło do niewłaściwego ujawnienia woli testatora. Zawsze jest on bowiem związany katalogiem możliwych do stwierdzenia wad oświadczenia woli, ich ustawowymi przesłankami oraz konsekwencjami ${ }^{63}$. Niezależnie od tego także ciężar dowodu, czy ograniczenie dopuszczalnego czasu dowodzenia stanowią dalsze przesłanki formalne, które nie pozwalają, by w pełni uwzględniać rzeczywisty stan psychiczny testatora.

\section{Wykładnia testamentu korygująca nieprawidłowe wyrażenie woli przez testatora}

Na oświadczenie woli tworzące czynność prawną składa się wyraz woli wewnętrznej wyrażonej w postaci uzewnętrznionego oświadczenia. Co do zasady to oświadczający ponosi swoiste ryzyko ukształtowania oświadczenia w taki sposób, że

58 Odmiennie - o tym, że w takiej sytuacji sąd powinien badać wady oświadczenia woli nawet po upływie terminów' przy czym takie rozumienie, z uwagi na funkcję przepisu - E. Skowrońska-Bocian, Testament..., op. cit., s. 219, jest wątpliwe chociażby w takim zakresie, w jakim pomija istnienie w przepisie terminów zawitych.

59 E. Skowrońska-Bocian, Testament..., op. cit., s. 217.

60 L. Stecki, (w:) J. Winiarz (red.), Kodeks..., op. cit., s. 849.

61 A. Mączyński, Wpływ..., op. cit., s. 40; Z. Radwański, Wykładnia testamentów, „Kwartalnik Prawa Prywatnego" 1993, nr 1.

62 B. Lewaszkiewicz-Petrykowska, Wady..., op. cit., s. 213; Z. Radwański, Wykładnia..., op. cit., s. 7; E. Skowrońska-Bocian, Testament..., op. cit., s. 44. 
jest niezgodne $\mathrm{z}$ jego wolą ${ }^{64}$. Korekta takiego stanu rzeczy dokonuje się za sprawą instytucji wad oświadczenia woli ${ }^{65}$, które pozwalają na uwzględnienie nieprawidłowego funkcjonowania woli lub niezgodności między wolą a jej przejawem ${ }^{66}$.

W przypadku testamentu powszechnie przyjmuje się, że ochrona rzeczywistej woli wewnętrznej testatora ma większe znaczenie niż w świetle ogólnych zasad. $\mathrm{Na}$ jej fundamentalne, rozstrzygające ${ }^{67}$ znaczenie wprost wskazuje treść art. $948 \$ 1$ kc., z którego wynika, że jedynym kryterium wykładni testamentu ma być najpełniejsze urzeczywistnienie woli spadkodawcy odpowiadające teorii woli ${ }^{68}$ i wynikającej z niej metody wykładni subiektywno-indywidualnej ${ }^{69}$. Tak daleka ochrona woli spadkodawcy, z pominięciem interesów innych podmiotów, jest przy tym możliwa w odniesieniu do aktu jednostronnego i odnoszącego skutki dopiero z chwilą śmierci testatora, a zatem w odniesieniu, do którego nie wchodzą w grę żadne inne interesy, które miałby chronić ustawodawca ${ }^{70}$.

Art. $948 \$ 2$ kc. w razie kilku możliwych interpretacji wedle warunków z $\$ 1$ każe przyjąć taką, która utrzyma rozrządzenia spadkodawcy w mocy i nada im rozsądną treść. W tym zakresie rozwija on $\$ 1$, w założeniu, że po to spadkodawca dokonuje rozrządzeń, żeby były skuteczne prawnie i rozsądne życiowo ${ }^{71}$, przy czym w razie kilku możliwych skutecznych interpretacji, wybrać należy tę najrozsądniejszą ${ }^{72}$.

Wykładnia jest jednak dopuszczalna wobec postanowień ważnego testamentu ${ }^{73}$ i prowadzić do interpretacji tylko tych postanowień, które rzeczywiście w nim zamieszczono i w których w choć niedoskonały sposób wyrażono wolę ${ }^{74}$. Spełnienie

Z. Radwański, (w:) Z. Radwański (red.), System prawa prywatnego. Tom 2, Część ogólna, Warszawa 2008, s. 59.

65 R. Trzaskowski, (w:) J. Gudowski (red.), Kodeks cywilny. Komentarz. Tom 1. Część ogólna, Warszawa 2013, s. 325.

66 K. Pietrzykowski, (w:) K. Pietrzykowski (red.), Kodeks cywilny. Tom. 1. Komentarz do art. 1-44910, Warszawa 2013.

67 S. Wójcik, F. Zoll, (w:) B. Kordasiewicz (red.), System..., op. cit., s. 349; podobnie postanowienie SN z dnia 23 stycznia 2008 r., V CSK 378/07, Lex nr 515714; postanowienie SN z dnia 21 listopada 2002 r., III CKN 1338/00, Lex nr 1162682.

68 Postanowienie SN z dnia 6 maja 2005 r., II CK 676/04, Lex nr 603159; M. Pazdan, (w:) K. Pietrzykowski (red.), Kodeks..., op. cit., s. 1024; J. Wierciński, Brak..., op. cit., s. 75.

69 Postanowienie SN z dnia 6 maja 2005 r., II CK 676/04; podobnie wyrok SN z dnia 6 października 2016 r., IV CSK 825/15, Lex nr 2191475; Z. Radwański, Wykładnia..., op. cit., s. 8.

70 B. Lewaszkiewicz-Petrykowska, (w:) S. Grzybowski (red.), System prawa cywilnego. Część ogólna. Tom 1, Warszawa 1985, s. 648; Z. Radwański, Wykładnia..., op. cit., s. 5-6.

71 Z. Radwański, Wykładnia..., op. cit., s. 8.

72 E. Skowrońska-Bocian, Testament..., op. cit., s. 26; o tym, że to domniemanie rozrządzeń rozsądnych - wyrok SN z dnia 6 października 2016 r., IV CSK 825/15.

73 Postanowienie SN z dnia 13 lutego 2001 r., II CKN 721/99, Lex nr 550940; wyrok SN z dnia 18 lutego 1999 r., I CKN 1002/97, Lex nr 521803; E. Skowrońska-Bocian, Testament..., op. cit., s. 25; Z. Radwański, Wykładnia..., op. cit., s. 9-10.

74 Postanowienie SN z dnia 6 maja 2005 r., II CK 676/04, Lex nr 603159; E. Skowrońska-Bocian, Testament..., op. cit., s. 27. 
tych wymogów może przecież stanowić problem osób składających oświadczenia w stanie mniejszej sprawności intelektualnej, w tym mniejszej świadomości prawnej. Ich brak doprowadzi jednak do tego, że nawet najbardziej życzliwa wykładnia woli testatora nie zastąpi wymogu wyrażenia tej woli w wymaganej prawem formie (a innymi słowy nie może prowadzić do sanowania braków formalnych czy treściowych testamentu) i nie doprowadzi do uzupełniania bądź modyfikowania wyrażonej woli ${ }^{75}$, czy też ustalenia woli rzeczywistej, choć w żaden sposób niewyrażonej ${ }^{76}$. Może jednak wykorzystać okoliczności spoza testamentu, w tym zwłaszcza kontekst wyrażenia woli, nie tylko do ustalenia, jaką treść nadano testamentowi ${ }^{77}$, ale także czy złożone oświadczenie w ogóle jest testamentem ${ }^{78}$, jeżeli tylko spełnia przesłanki jego ważności.

Wykładnia może stanowić sposób na usunięcie skutków oświadczenia złożonego niezgodnie $\mathrm{z}$ wolą, bez potrzeby kierowania się do negatywnego skutku regulacji wad oświadczenia woli - a to poprzez wybór takiej interpretacji oświadczenia, która będzie dopuszczalna w świetle jego treści i zarazem zgodna z rzeczywistą wolą. Wszakże skoro testator zdecydował się sporządzić testament, to tym samym chciał zmienić porządek dziedziczenia ustawowego ${ }^{79}$, a zatem podważenie testamentu z uwagi na wady oświadczenia woli powinno być traktowane jako ostateczny środek prawny, gdy z pomocą wykładni nie będzie możliwe osiągnięcie właściwych celów ${ }^{80}$. Nieprecyzyjność wyrażenia woli w testamencie nie może prowadzić w tym zakresie do jego nieważności ${ }^{81}$. Gdy jednak wyrażona wola będzie sprzeczna z wolą rzeczywistą, jedynym sposobem doprowadzania do niewywoływania przez nią skutków będą przepisy o wadach oświadczenia woli ${ }^{82}$.

Specyficzne reguły wykładni testamentu nie abstrahują jednakże od wymogów z art. 65 kc., które szczególnie starannie omawia Z. Radwański. W szczególności

75 Postanowienie SN z dnia 21 października 2016 r., IV CSK 837/15, Lex nr 2148635; postanowienie SN z dnia 6 maja 2005 r., II CK 676/04, Lex nr 603159; wyrok SN z dnia 18 lutego 1999 r., I CKN 1002/97, Lex nr 521803; E. Skowrońska-Bocian, Testament..., op. cit., s. 25; E. Skowrońska-Bocian, J. Wierciński, (w:) J. Gudowski (red.), Kodeks..., op. cit., s. 130.

76 E. Skowrońska-Bocian, Testament..., op. cit., s. 220.

77 Postanowienie SN z dnia 6 maja 2005 r., II CK 676/04, Lex nr 603159.

78 Postanowienie SN z dnia 21 października 2016 r., IV CSK 837/15, Lex nr 2148635.

79 S. Wójcik, F. Zoll, (w:) B. Kordasiewicz (red.), System..., op. cit., s. 353.

80 Z. Radwański, Wykładnia..., op. cit., s. 8, 25; E. Skowrońska-Bocian, Testament..., s. 26-27; S. Wójcik, F. Zoll, (w:) B. Kordasiewicz (red.), System..., op. cit., s. 353.

81 Postanowienie SN z dnia 29 kwietnia 2009 r., II CSK 637/08, Lex nr 610215.

82 Z. Radwański, Wykładnia..., op. cit., s. 22-24. 
$\mathrm{z}$ art. $65 \$ 1 \mathrm{kc}$. pod uwagę należy wziąć $c^{83}$ : kontekst sytuacyjny dotyczący testatora ${ }^{84}$, ustalone zwyczaje ${ }^{85}$; a ponadto zasady współżycia społecznego ${ }^{86}$. Z kolei zbliżone do funkcji art. $65 \$ 2 \mathrm{kc}$. jest nadanie priorytetu celowi rozrządzeń bardziej niż ich dosłownej treści. Ten cel, odnoszony wprawdzie tylko do jednej osoby - testatora - ma mieć nawet większe znaczenie niż w przypadku umów ${ }^{87}$. Ekscentryzm celu, podobnie jak przy ocenie świadomości rozrządzenia, wymaga szczególnego dowodu na jego rzeczywisty charakter ${ }^{88}$. W dalszej kolejności, jeżeli ustalenia woli testatora dalej nie dają jednoznacznych wyników, możliwe jest skorzystanie chociażby z przepisu art. 961 kc., którego zadaniem jest rozróżnienie z pomocą wykładni sytuacji powołania osoby do spadku od zapisu w wypadku, kiedy w testamencie przeznaczono jej konkretne składniki spadku ${ }^{89}$.

To, czy przepisy o wykładni testamentu będą zastosowane do aktów powodujących przejście majątku na wypadek śmierci na podstawie przepisów szczególnych, w drodze analogii, powinno zostać rozstrzygnięte, jak w zasygnalizowanym wyżej przypadku wad oświadczenia woli. Przesądza o tym podobieństwo funkcji regulacji i sytuacji prawnej, której dotyczy.

\section{Podsumowanie}

Choć polskie prawo spadkowe opiera się na założeniu szczególnej ochrony woli testatora, analiza rzeczywistego uwzględniania jego woli na przykładzie testatora będącego osobą z zaburzeniami psychicznymi wykazuje ich znaczące granice i liczne dopuszczalne prawem sytuacje, w których wiążące ustalenia co do woli testatora będą rażąco sprzeczne z jego rzeczywistą wolą, w tym nawet taką, która jest znana.

W szczególności do rozważenia pozostaje kwestia pozbawienia osoby nieposiadającej pełnej zdolności do czynności prawnych w całości zdolności testowania. W tym zakresie chociażby regulacja $\$$ 2-501 amerykańskiego prawa modelowego

83 Wraz z przykładami Z. Radwański, Wykładnia..., op. cit., s. 12-13; o tym, że jednak w ograniczonym zakresie wyrok SN z dnia 6 października 2016 r., IV CSK 825/15; o tym, że po dokonaniu wykładni na podstawie przepisów szczególnych wprost - postanowienie SN z dnia 14 maja 2015 r., I CSK 489/14, Lex nr 1767089.

84 Okoliczności składania przez niego oświadczenia woli, w tym jego wypowiedzi pozatestamentowe, które jednak należy brać pod uwagę z dystansem, bo niekoniecznie mogą wyrażać jego rzeczywistą i np. skrywaną na zewnątrz wolę.

85 Istotne zwłaszcza z punktu widzenia reguł znaczeniowych wyrażonych oświadczeń utrwalonych w grupie społecznej, z której pochodzi.

86 Stanowić mają subsydiarną dyrektywę nakazującą założenie, że testator jest osobą przyzwoitą, bierze pod uwagę los osób bliskich lub w potrzebie.

87 Z. Radwański, Wykładnia..., op. cit., s. 12-14.

88 Ibidem, s. 29.

89 Postanowienie SN z dnia 14 maja 2015 r., I CSK 489/14; podobnie postanowienie SN z dnia 23 stycznia 2008 r., V CSK 378/07; postanowienie SN z dnia 21 listopada 2002 r., III CKN 1338/00. 
Uniform Probate Code (UPC) wskazuje, że dla samej zdolności testowania wymagane jest ukończenie wieku 18 lat oraz posiadanie sprawnego umysłu (sound mind) badane w okolicznościach konkretnego przypadku, a zatem inaczej niż w prawie polskim utrzymującym znaczenie przesłanek formalnych braku ubezwłasnowolnienia oraz braku specyficznych wad oświadczenia woli. Przed konsekwencjami czynności dokonanych w stanie braku odpowiedniej świadomości i swobody testator chroniony jest bowiem za pomocą instytucji prawnych biorących pod uwagę jego rzeczywistą zdolność wyrażenia woli i pozbawionych elementów formalnych. W szczególności jest nim brak upośledzenia umysłowego (mental deficiency) wiążącego się z niezrozumieniem procesu sporządzania testamentu i jego skutków prawnych; urojenia (insane delusion), czyli rozrządzenia pod wpływem nieracjonalnych decyzji; jak również nadmiernego wpływu (undue influence) innych osób na testatora, w tym zwłaszcza pozostających w relacji zaufania ${ }^{90}$.

Ponadto nawet najbardziej niewątpliwe wyrażenie woli przez spadkodawcę bez spełnienia jej formy, czy bez zdolności testowania, które w świetle prawa polskiego nie będzie mogło być w żaden sposób uwzględnione, znajduje uznanie w $\$ 2$-503 UPC. W jego świetle, w razie braku zgodności dokumentu $\mathrm{z}$ wymogami formy dla testamentu, za to przy jasnych i przekonujących dowodach (clear and convincing evidence), że dokument wyraża wolę testatora, powinno się traktować go, jak gdyby był sporządzony właściwie.

Obydwa te przykłady pokazują istniejącą możliwość szerszej ochrony woli spadkodawcy, niezależnej od przesłanek formalnych, a uzależnionej od tego, by była ona jasno i niewątpliwie wyrażona. Zachęcają również do rozważenia, czy w sytuacji, w której specyfika praktyki prawa spadkowego się zmienia - wzrasta majętność i długowieczność społeczeństwa, tendencja do wykorzystywania instytucji ubezwłasnowolnienia w celu przejęcia kontroli nad majątkiem, a zarazem pogarsza się stan psychiczny testatorów starzejących się i cierpiących na coraz większe zaburzenia psychiczne - zwiększeniu, np. na wzór amerykański, powinno ulec także uznanie rzeczywistej woli spadkodawcy.

\section{BIBLIOGRAFIA}

Andersen R.W., I.M. Bloom, Fundamentals of Trusts and Estates, wyd. 2, 2002.

Grzybowski S., (w:) S. Grzybowski (red.), System prawa cywilnego. Część ogólna. Tom 1, Warszawa 1985.

Gwiazdomorski J., Wyjaśnienie w związku z artykułem M. Piekarskiego „Wpływ zakłócenia czynności psychicznych stron na tok procesu”, „Państwo i Prawo” 1961, nr 12.

Kowanetz M., Skupień E., Możliwości oceny świadomości i swobody podejmowania decyzji w trakcie dokonywania czynność przez notariuszy, „Rejent” 2009, nr 7-8.

90 R.W. Andersen, I.M. Bloom, Fundamentals of Trusts and Estates, wyd. 2, 2002, s. 178-188. 
Kremis J., (w:) E. Gniewek, P. Machnikowski (red.), Kodeks cywilny. Komentarz, Warszawa 2013.

Lewaszkiewicz-Petrykowska B., (w:) S. Grzybowski (red.), System prawa cywilnego. Część ogólna. Tom 1, Warszawa 1985.

Lewaszkiewicz-Petrykowska B., Wady oświadczenia woli przy sporządzaniu testamentu, (w:) B. Kordasiewicz, E. Łętowska (red.), Prace z prawa cywilnego wydane dla uczczenia pracy naukowej profesora Józefa Stanisława Piątowskiego, Wrocław 1985.

Longchamps de Berier F., (w:) W. Dajczak, T. Giaro, F. Longchamps de Berier, Prawo rzymskie. U podstaw prawa prywatnego, Warszawa 2009.

Mączyński A., Wpływ wad oświadczenia woli na ważność testamentu, „Rejent” 1991, nr 7-8.

Pazdan M., (w:) K. Pietrzykowski (red.), Kodeks cywilny. Komentarz do art. 450-1088, Warszawa 2013.

Pazdan M., (w:) M. Safjan (red.), System prawa prywatnego. Część ogólna. Tom 1, Warszawa 2012.

Piątowski J., Prawo spadkowe, Warszawa 2014.

Pietrzykowski K., (w:) K. Pietrzykowski (red.), Kodeks cywilny. Komentarz do art. 1-449 ${ }^{10}$, Warszawa 2013.

Pionkowski J., Nieważność testamentów osób wykazujących zaburzenia psychiczne, „Nowe Prawo” 1963, nr 2.

Radwański Z., (w:) Z. Radwański (red.), System prawa prywatnego. Część ogólna. Tom 2, Warszawa 2008 .

Radwański Z., Wykładnia testamentów, „Kwartalnik Prawa Prywatnego” 1993, nr 1.

Skowrońska-Bocian E., (w:) J. Gudowski (red.), Kodeks cywilny. Komentarz. Spadki. Tom 4, Warszawa 2013.

Skowrońska-Bocian E., Testament w prawie polskim, Warszawa 2004.

Skowrońska-Bocian E., Wierciński J., (w:) J. Gudowski (red.), Kodeks cywilny. Komentarz. Spadki. Tom 4, Warszawa 2013.

Stecki L., (w:) J. Winiarz (red.), Kodeks cywilny z komentarzem, Warszawa 1980.

Trzaskowski R., (w:) J. Gudowski (red.), Kodeks cywilny. Komentarz. Część ogólna. Tom 1, Warszawa 2013.

Wierciński J., Brak świadomości albo swobody przy sporządzaniu testamentu, Warszawa 2013.

Wójcik S., (w:) J. Piątowski (red.), System prawa cywilnego. Prawo spadkowe, Warszawa 1986.

Wójcik S., Zoll F., (w:) B. Kordasiewicz (red.), System prawa prywatnego. Prawo spadkowe. Tom 10, Warszawa 2015. 